\title{
Application of Mathematical Function to Estimate the Compaction Characteristics of Unsaturated Soils
}

\author{
Armand Augustin Fondjo", Elizabeth Theron \\ Department of Civil Engineering, Central University of Technology, South Africa
}

Received September 1, 2020; Revised November 12, 2020; Accepted November 29, 2020

\section{Cite This Paper in the following Citation Styles}

(a): [1] Armand Augustin Fondjo, Elizabeth Theron, "Application of Mathematical Function to Estimate the Compaction Characteristics of Unsaturated Soils," Civil Engineering and Architecture, Vol. 9, No. 1, pp. 255 - 262, 2021. DOI: 10.13189/cea.2021.090121.

(b): Armand Augustin Fondjo, Elizabeth Theron (2021). Application of Mathematical Function to Estimate the Compaction Characteristics of Unsaturated Soils. Civil Engineering and Architecture, 9(1), 255 - 262. DOI: 10.13189/cea.2021.090121.

Copyright $(2021$ by authors, all rights reserved. Authors agree that this article remains permanently open access under the terms of the Creative Commons Attribution License 4.0 International License

\begin{abstract}
The study aims to propose a mathematical approach to determine the optimum moisture content $\left(\mathrm{W}_{\mathrm{OP}}\right)$ and the corresponding maximum dry unit weight $\left(\gamma_{\mathrm{dmax}}\right)$ of unsaturated fine-grained clay soils with accuracy. Laboratory tests such as grain size distribution, Atterberg limits, specific gravity, Proctor compaction test, and soil suction measurement are conducted to assess soil properties. The $\mathrm{W}_{\mathrm{OP}}$ and $\gamma_{\mathrm{dmax}}$ are determined using the mathematical approach based on differential function $(\partial)$ and the graphical method. The differences in optimum moisture content values between the mathematical approach and the graphical method $\left(\Delta \mathrm{W}_{\mathrm{OP}}\right)$ values are $0.43 \%, 0.36 \%, 0.42 \%, 0.24 \%$, respectively for soils PES, $\mathrm{BFS}$, WIS, BES, and induced differences in total suction of $179.17 \mathrm{kPa}, \quad 144.00 \mathrm{kPa}, \quad 175.00 \mathrm{kPa}, 96.00 \mathrm{kPa}$, respectively for soils PES, BFS, WIS, BES. Moreover, the differences in matric suction are $148.27 \mathrm{kPa}, 116.13 \mathrm{kPa}$, $144.83 \mathrm{kPa}, 80.00 \mathrm{kPa}$, respectively for soils PES, BFS, WIS, BES. $\Delta \mathrm{W}_{\mathrm{OP}}$ and $\Delta_{\gamma d \max }$ values are smaller than $0.5 \%$ and marginal in the context of saturated soil mechanics. However, the total suction and matric suction values induced by $\Delta \mathrm{W}_{\mathrm{OP}}$ values are significant for unsaturated soils. An accurate estimation of $\gamma_{\mathrm{dmax}}$ and $\mathrm{W}_{\mathrm{OP}}$ can be performed on unsaturated compacted soils using the mathematical approach.
\end{abstract}

Keywords Mathematical Approach, Graphical Method, Compaction Parameters, Soil Suction

\section{Introduction}

In 1933 Proctor developed a compaction test in the lab to assess the maximum dry unit weight $\left(\gamma_{\mathrm{dmax}}\right)$ of compacted soils used for field compaction requirements [1]. Compaction is the densification and rearrangement of soil particles by removing air void using mechanical equipment such as a compaction machine. Soil compaction with carefully controlled moisture content improves the shear stress, slope stability of embankment, bearing limit of soil in the construction of buildings, roads, and other engineering structures. Also, compaction diminishes the quantity of unwanted settlement of constructions and the compressibility of soil support. The compaction parameters of soil are obtained from the lab compaction test. A steady value of applied energy to a specific soil specimen at $\mathrm{W}_{\mathrm{OP}}$ induces a $\gamma_{\mathrm{dmax}}$. The $\mathrm{W}_{\mathrm{OP}}$ is required to provide the best path to enter energy into the soil and compact it. The $\mathrm{W}_{\mathrm{OP}}$ and $\gamma_{\mathrm{dmax}}$ are fundamental indexes in the analysis of compacted soil behaviour. Researchers like $[2,3,4,5]$ have described in detail the various methods for obtaining $\mathrm{W}_{\mathrm{OP}}$ and $\gamma_{\mathrm{dmax}}$ of clayey soils from proctor compaction. However, in the compaction test method, the $\mathrm{W}_{\mathrm{OP}}$ and corresponding $\gamma_{\mathrm{d} \max }$ are determined under the prerequisite of a given compaction work and adopted according to standard [6]. In practice, $\mathrm{W}_{\mathrm{OP}}$ and $\gamma_{\mathrm{dmax}}$ are commonly estimated graphically from the compaction curve. References [7,8,9,10,11] proposed equations to predict the compaction characteristics. Nevertheless, these equations do not consider the effect of soil suction on compaction parameters. Moreover, [12] 
proposed a technique to assess the $\mathrm{W}_{\mathrm{OP}}$ of fine-grained soils utilizing a non-linear ultrasonic. Reference [13] proposed an arithmetic approach to assess the $\mathrm{W}_{\mathrm{OP}}$. Nonetheless, the non-linear ultrasonic technique and the arithmetic approach cannot estimate the $\gamma_{\mathrm{d} \max }$. In general, the precedent research works related to the determination of the $\mathrm{W}_{\mathrm{OP}}$ and $\gamma_{\mathrm{dmax}}$ are based on saturated soils and do not consider the effect of suction on the estimation of the $\mathrm{W}_{\mathrm{OP}}$ and $\gamma_{\mathrm{dmax}}$. The primary objective of this current research work is to propose a mathematical approach to accurately determine the $\mathrm{W}_{\mathrm{OP}}$ and the corresponding $\gamma_{\mathrm{dmax}}$ of unsaturated fine-grained clay soils.

\section{Material and Testing Program}

\subsection{Material}

The type of soil plays an essential role in the compaction parameter values. In this current study, soil samples are collected from the site by digging. Soil samples are selected in a manner to obtain different gradations and consistency limit values so that to encompass a wide range of soil suction and display the effect of suction on the determination of compaction characteristics. Table 1 shows the material properties of soil samples.

\subsection{Testing Program}

The assessment of the soil's physical and hydro-mechanical properties is performed according to the laid down protocols and standards found in the literature. Sieve analysis [14], hydrometer analysis [15], Atterberg limits [16], compaction test [6], soil suction measurement using the filter paper method [17].

\subsubsection{Soil suction measurement}

The calibration curve Equation (1) derives from the Whatman No42 filter paper calibration using a salt solution. Equation (2) is utilized to determine the moisture content inside the filter paper $\left(\mathrm{W}_{\mathrm{f}}\right)$. The substitution of the moisture content value $\left(\mathrm{W}_{\mathrm{f}}\right)$ in Equation (1) gives the soil suction. Compacted cylindrical soil specimens are split into two parts with a width of $75 \mathrm{~mm}$ and a deepness of 35 $\mathrm{mm}$ so that the soil specimen can be placed and withdrawn from the glass container easily. See Figure 1. Soil suction is estimated utilizing the Whatman No 42 filter paper (Ashless circles $70 \mathrm{~mm}$ diameter Cat No 1442-070). Three filter papers: two protectives and one for suction evaluation are set between the two surfaces utilizing tweezers to estimate the matric suction. The two specimen parts are joined by electrical tape and inserted into the glass container. A plastic ring is put on the specimen, and the filter paper is set on the plastic ring to gauge the total suction. The glass containers are sealed, named, and put into a temperature regulatory equipment at $25 \pm 1^{\circ} \mathrm{C}$ for an equilibrium period of one month. Filter papers are oven-dried to expel moisture and guarantee that a similar wetting way is followed for each situation to prevent hysteresis effect (Swarbrick, 1995). Moisture cans are oven-dried at $105^{\circ} \mathrm{C}$ overnight. The filter paper moisture content is estimated utilizing a $0.0001 \mathrm{~g}$ readable balance. The mass of moisture in the filter paper is $\left(\mathrm{M}_{\mathrm{w}}\right)$. The mass of filter paper is $\left(\mathrm{M}_{\mathrm{f}}\right)$. The relation (1) below describes the soil suction $(\psi)$ in $\mathrm{kPa}$.

$$
\log (\psi)=-0.0791 \times \mathrm{W}_{\mathrm{f}}+5.313
$$

$$
\mathrm{W}_{\mathrm{f}}=\frac{\mathrm{M}_{\mathrm{w}}}{\mathrm{M}_{\mathrm{f}}} \times 100
$$

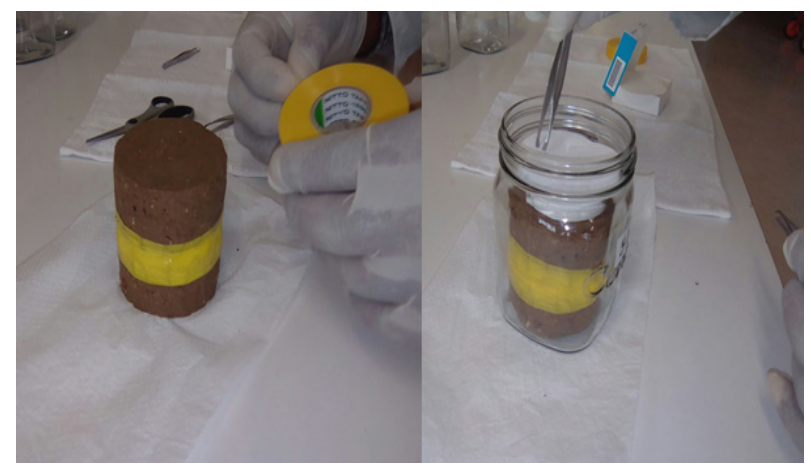

Figure 1. Soil suction measurement test

\subsubsection{Proctor compaction test}

The test is performed using a mould with separable collard, a compacting base plate with a thick spacer plate as illustrated in Figure 2. Samples are sieved using a 4750 -micron sieve. Roughly $35 \mathrm{~kg}$ of the specimen is oven-dried at $105^{\circ} \mathrm{C}$ for 16 to 24 hours and divided into five bowls of similar material. The compaction blows are distributed evenly over the total layer. After tamping the first layer, the depth of the surface of the tamped material is measured without the collard. The tamping of four additional layers is identical. After compaction, a typical specimen is taken from the material to assess the moisture content. A wet soil specimen is weighed with accuracy to the nearest 0.1 gram and dried in the oven at $105^{\circ} \mathrm{C}$. The other points of compaction curves are determined using the same process. The dry unit weight $\left(\gamma_{\mathrm{d}}\right)$ is obtained for each moisture content. $(\gamma)$ is the bulk dry unit weight, $(\mathrm{W})$ is the moisture content, and $\left(\gamma_{\mathrm{d}}\right)$ is described by Equation (3).

$$
\gamma_{d}=\frac{\gamma}{1+\frac{W}{100}}
$$




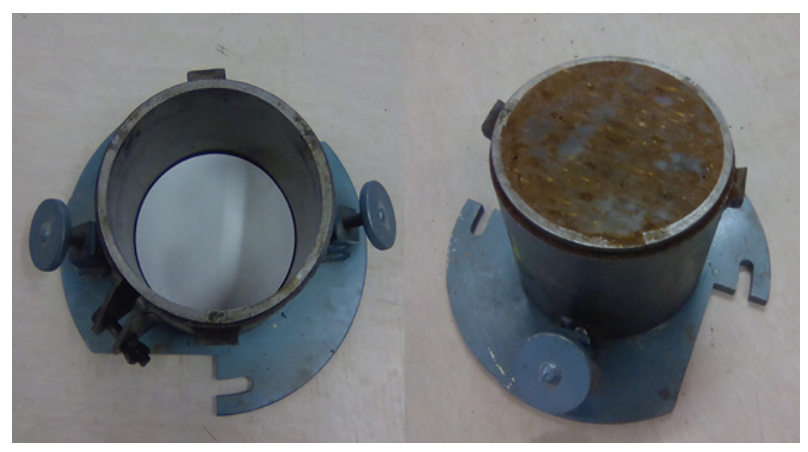

Figure 2. Proctor compaction test

\subsection{Mathematical Approach to Estimate the Maximum Dry Unit Weight and the Optimum Moisture Content}

Data obtained from the compaction test are utilized to plot the compaction curve graph using the EXCEL Program. The fitting equations such as linear, logarithmic, inverse, quadratic, cubic, power, compound, growth, exponential are analyzed. The cubic equation exhibits the best-fitting equation. Besides, the compaction curve graph uses two parameters: the dry unit weight $\left(\gamma_{\mathrm{d}}\right)$ and moisture content $(\mathrm{W})$. Therefore, in the mathematical concept, $\gamma_{\mathrm{d}}$ can be expressed as a function of $W$ as follows: $\gamma_{d}=f(W)$. Further, the bulk dry unit weight $(\gamma)$ is the ratio of compacted soil weight and the volume of the mould at each specific $\mathrm{W}$ in the compacted specimen. The calculation of the $\gamma$ is required before obtaining $\gamma_{\mathrm{d}}$. Therefore, the mathematical approach function considers both $\mathrm{W}$ and $\gamma$. Moreover, the third-degree mathematical function $\gamma_{d}=f(w)$ describes the best fitting compaction curve with a determination coefficient $\mathrm{R}^{2} \approx 1$. Therefore, the mathematical function takes the form of a third-order Equation (4) with constant real number values (a, b, c, d).

$$
\begin{gathered}
\gamma_{\mathrm{d}}=\mathrm{a} \times \mathrm{W}^{3}+\mathrm{b} \times \mathrm{W}^{2}+\mathrm{c} \times \mathrm{W}+\mathrm{d}, \quad \mathrm{R}^{2} \approx 1 \\
\mathrm{a}, \mathrm{b}, \mathrm{c}, \mathrm{d} \in \mathrm{R}
\end{gathered}
$$

Equation (4) of the compaction curve is differentiated by the moisture content (W) using a partial differential function $(\partial)$ as follows:

$$
\begin{gathered}
\frac{\partial\left(\gamma_{d}\right)}{\partial W}=\frac{\partial}{\partial W}\left(a \times W^{3}+b \times W^{2}+c \times W+d\right) \\
\frac{\partial\left(\gamma_{d}\right)}{\partial W}=\frac{\partial\left(a \times W^{3}\right)}{\partial W}+\frac{\partial\left(b \times W^{2}\right)}{\partial W}+\frac{\partial(c \times W)}{\partial W}+\frac{\partial(d)}{\partial W} \\
\frac{\partial\left(\gamma_{d}\right)}{\partial W}=a \times \frac{\partial\left(W^{3}\right)}{\partial W}+b \times \frac{\partial\left(W^{2}\right)}{\partial W}+c \times \frac{\partial(W)}{\partial W} \\
\frac{\partial\left(\gamma_{d}\right)}{\partial W}=3 a \times W^{2}+2 b \times W+c
\end{gathered}
$$

The optimum moisture content $\left(\mathrm{w}_{\mathrm{OP}}\right)$ is determined by solving Equation (9) below.

$$
\begin{gathered}
\frac{\partial\left(\gamma_{d}\right)}{\partial W}=0 \\
3 a \times W_{O P}^{2}+2 b \times W_{O P}+c=0
\end{gathered}
$$

The $\mathrm{W}_{\mathrm{OP}}$ is selected as the workable value among the two solutions of Equation (11). Besides, the $\gamma_{\mathrm{dmax}}$ is obtained by substituting the $\mathrm{W}_{\mathrm{OP}}$ in the compaction curve Equation (4) as follows:

$$
\gamma_{\mathrm{dmax}}=\mathrm{a} \times \mathrm{W}_{\mathrm{OP}}^{3}+\mathrm{b} \times \mathrm{W}_{\mathrm{OP}}^{2}+\mathrm{c} \times \mathrm{W}_{\mathrm{OP}}+\mathrm{d}
$$

\section{Results and Discussions}

\subsection{Material Properties}

The material properties of the soil samples are summarized in Table 1. PES, BFS, WIS are fine-grained soil, more than $50 \%$ passing sieve No $200(0.075 \mathrm{~mm})$. Also, the liquid limit values of BLS, WBS, and WKS are greater than $50 \%$ above the A-line of the plasticity chart. Thus, these soils exhibit high plasticity and classified $(\mathrm{CH})$. Besides, for BES soil, 49.50\% passing sieve No 200 $(0.075 \mathrm{~mm})$. Nonetheless, BES contained more fine-grained soils than sand and gravel. The liquid limit value is less than $50 \%$ above the A-line of the plasticity chart. Then, BES displays low plasticity and classified (CL).

Table 1. Material properties

\begin{tabular}{|c|c|c|c|c|c|c|c|c|}
\hline $\begin{array}{c}\text { Soil } \\
\text { designation }\end{array}$ & $\begin{array}{c}\text { Liquid limit, } \\
\text { (LL) } \\
\%\end{array}$ & $\begin{array}{c}\text { Plasticity index } \\
\text { (PI) } \\
\%\end{array}$ & $\begin{array}{c}\text { Specific } \\
\text { gravity } \\
\text { (Gs) }\end{array}$ & $\begin{array}{c}\text { Clay } \\
\%\end{array}$ & $\begin{array}{c}\text { Fine } \\
\%\end{array}$ & $\begin{array}{c}\text { Sand } \\
\%\end{array}$ & $\begin{array}{c}\text { Gravel } \\
\%\end{array}$ & USCS \\
\hline PES & 54.83 & 34.87 & 2.66 & 29.85 & 58.45 & 27.69 & 13.86 & $\mathrm{CH}$ \\
\hline BFS & 61.27 & 38.25 & 2.68 & 32.20 & 61.82 & 28.49 & 9.69 & $\mathrm{CH}$ \\
\hline WIS & 66.22 & 44.10 & 2.76 & 36.50 & 69.10 & 28.20 & 2.40 & $\mathrm{CH}$ \\
\hline BES & 48.37 & 23.09 & 2.63 & 20.00 & 49.50 & 44.00 & 6.30 & $\mathrm{CL}$ \\
\hline
\end{tabular}




\subsection{Hydro-mechanical Properties Analysis}

\subsubsection{Proctor compaction test}

The $\mathrm{W}_{\mathrm{OP}}$ and $\gamma_{\mathrm{dmax}}$ are determined from compaction curves using the mathematical approach and graphical method for soils PES, BFS, WIS, BES presented in Figures $3,4,5 \& 6$. As a result, WIS exhibits smaller $\gamma_{\mathrm{dmax}}$ values and higher $\mathrm{W}_{\mathrm{OP}}$ values. Further, BES soil displays higher $\gamma_{\mathrm{dmax}}$ values and smaller $\mathrm{W}_{\mathrm{OP}}$ values. PES and BFS soil exhibit $\gamma_{\mathrm{dmax}}$ and $\mathrm{W}_{\mathrm{OP}}$ mean values. The results based on the mathematical approach and the graphical method are shown in Table 2. The results are justified by the fact that when the fine-grained (Clay+Silt) content increases, the $\gamma_{\text {dmax }}$ decreases, and the $W_{O P}$ increases upon the same compaction energy. Likewise, WIS consists of a higher fine-grained fraction of $69.10 \%$ when BES consists of a smaller fine-grained fraction of $49.50 \%$. BFS and PES consist of a mean fine-grained fraction respective of $61.82 \%, 58.54 \%$. Therefore, the $\gamma_{\mathrm{dmax}}$ and $\mathrm{W}_{\mathrm{OP}}$ are a function of fine-grained soils. Moreover, the differences in $\mathrm{W}_{\mathrm{OP}}$ value between mathematical approach and graphical method denoted by $\left(\Delta \mathrm{W}_{\mathrm{OP}}\right)$ are $0.43 \%, 0.36 \%, 0.42 \%$, $0.24 \%$ respectively for soils PES, BFS, WIS, BES, which are less than $0.50 \%$ and marginal in the context of saturated soil mechanics. Besides, the differences in $\gamma_{\mathrm{dmax}}$ values between mathematical approach and graphical method $\left(\Delta \gamma_{\text {dmax }}\right)$ are $0.02 \mathrm{kN} \cdot \mathrm{m}^{-3}, 0.11 \mathrm{kN} \cdot \mathrm{m}^{-3}, 0.41 \mathrm{kN} \cdot \mathrm{m}^{-3}$, $0.14 \mathrm{kN} . \mathrm{m}^{-3}$, respectively for soils PES, BFS, WIS, BES are less than $0.50 \%$ and marginal. By and large, the compaction parameters $\left(\mathrm{W}_{\mathrm{OP}}, \gamma_{\mathrm{dmax}}\right)$ determined by the mathematical approach and graphical method are nearly similar. Nevertheless, section 3.3 describes the assessment of the impact of the difference in $\mathrm{W}_{\mathrm{OP}}$ between the mathematical and graphical technique $\left(\Delta \mathrm{W}_{\mathrm{OP}}\right)$ on total suction and matric suction in unsaturated soils.

Table 2. Compaction test results

\begin{tabular}{|c|c|c|c|c|}
\hline \multirow{2}{*}{$\begin{array}{c}\text { Soil } \\
\text { designation }\end{array}$} & \multicolumn{2}{|c|}{ Mathematical approach } & \multicolumn{2}{|c|}{ Graphical method } \\
\hline & $\begin{array}{c}\mathrm{w}_{\mathrm{opt}} \\
\%\end{array}$ & $\begin{array}{c}\gamma_{\mathrm{dmax}} \\
\text { kN. } \mathrm{m}^{-3}\end{array}$ & $\begin{array}{c}\mathrm{w}_{\mathrm{opt}}^{\prime} \\
\%\end{array}$ & $\begin{array}{l}\gamma_{\mathrm{dmax}}^{\prime} \\
\mathrm{kN} \cdot \mathrm{m}^{-3}\end{array}$ \\
\hline PES & 20.38 & 18.00 & 19.95 & 17.98 \\
\hline BFS & 22.61 & 17.16 & 22.25 & 17.27 \\
\hline WIS & 24.58 & 16.71 & 25.00 & 16.73 \\
\hline BES & 18.24 & 18.76 & 18.00 & 18.90 \\
\hline
\end{tabular}

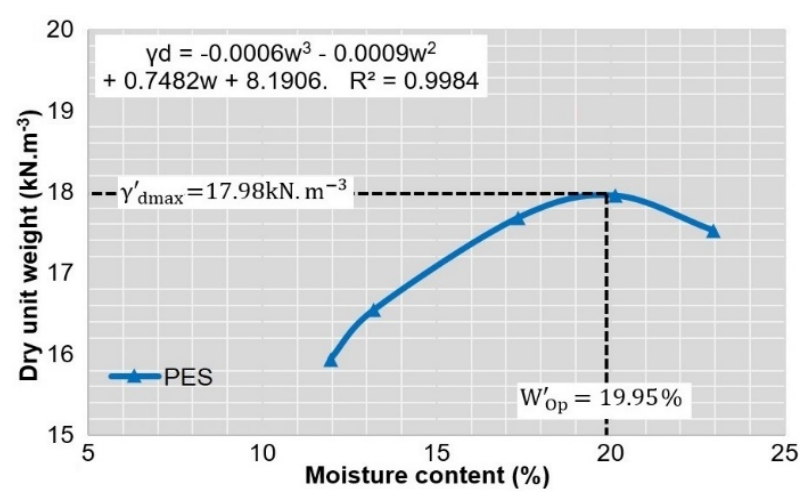

Figure 3. Compaction curve graph, $\gamma_{\mathrm{d}}=f(\mathrm{~W})$, (PES)
Compaction characteristic values $\left(\gamma_{\mathrm{dmax}}, \mathrm{W}_{\mathrm{OP}}\right)$ of PES fine-grained soils are obtained using the graphical method.

$$
\begin{gathered}
W^{\prime}{ }_{O P}=19.95 \% \\
\gamma_{\text {dmax }}^{\prime}=17.98 \mathrm{kN} \cdot \mathrm{m}^{-3}
\end{gathered}
$$

Compaction characteristic values $\left(\gamma_{\mathrm{dmax}}, \mathrm{W}_{\mathrm{OP}}\right)$ of PES fine-grained soils are obtained using the mathematical approach.

$$
\begin{gathered}
\gamma_{\mathrm{d}}=-0.0006 \mathrm{~W}^{3}-0.0009 \mathrm{~W}^{2}+ \\
+0.7482 \mathrm{~W}+8.1906 \\
\frac{\partial\left(\gamma_{\mathrm{d}}\right)}{\partial \mathrm{w}}=-0.0018 \mathrm{~W}^{2}-0.0018 \mathrm{~W}+0.7492 \\
\frac{\partial\left(\gamma_{\mathrm{d}}\right)}{\partial \mathrm{W}}=0 \text { say }-0.0018 \mathrm{~W}_{\mathrm{OP}}^{2}-0.0018 \mathrm{~W}_{\mathrm{OP}} \\
+0.7482=0 \\
\mathbf{W}_{\mathrm{OP}}=\mathbf{2 0 . 3 8} \% \\
\gamma_{\mathrm{dmax}}=-0.0006 \mathrm{~W}_{\mathrm{OP}}^{3}-0.0009 \mathrm{~W}_{\mathrm{OP}}^{2}+ \\
+0.7482 \mathrm{~W}_{\mathrm{OP}}+8.1906(19) \\
\gamma_{\mathrm{dmax}}=-0.0006\left(20.38^{3}\right)-0.0009\left(20.38^{2}\right)+ \\
+0.7482(20.38)+8.1906 \\
\boldsymbol{\gamma}_{\mathrm{d} \max }=\mathbf{1 8 . 0 0} \mathbf{k N} . \mathbf{m}^{-3}
\end{gathered}
$$

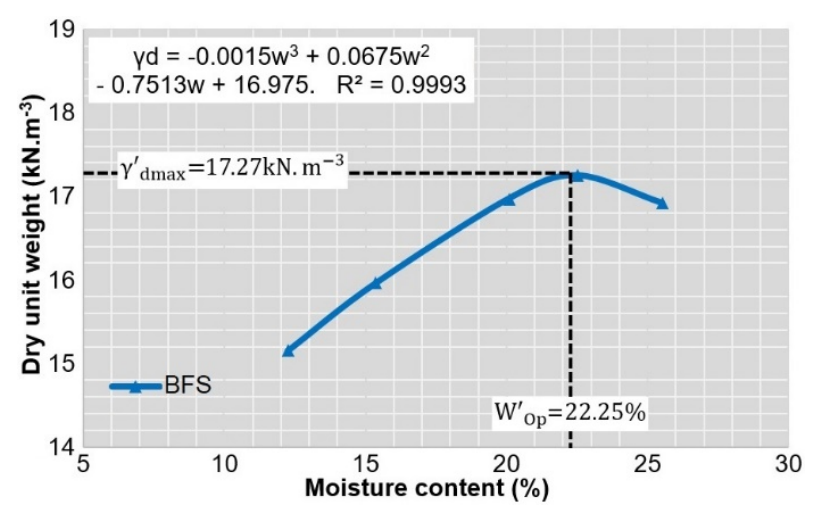

Figure 4. Compaction curve graph, $\gamma_{\mathrm{d}}=f(\mathrm{~W}),(\mathrm{BFS})$

Compaction characteristic values $\left(\gamma_{\mathrm{dmax}}, \mathrm{W}_{\mathrm{OP}}\right)$ of $\mathrm{BFS}$ fine-grained soils are obtained using the graphical method.

$$
\begin{gathered}
\mathbf{W}^{\prime}{ }_{\text {OP }}=22.25 \% \\
\gamma_{\text {dmax }}^{\prime}=17.27{\mathrm{kN} . \mathrm{m}^{-3}}^{-3}
\end{gathered}
$$

Compaction characteristic values $\left(\gamma_{\mathrm{dmax}}, \mathrm{W}_{\mathrm{OP}}\right)$ of $\mathrm{BFS}$ fine-grained soils are obtained using the mathematical approach.

$$
\begin{gathered}
\gamma_{\mathrm{d}}=-0.0015 \mathrm{~W}^{3}+0.0675 \mathrm{~W}^{2}- \\
-0.7513 \mathrm{~W}+16.975 \\
\frac{\partial\left(\gamma_{\mathrm{d}}\right)}{\partial \mathrm{w}}=-0.0045 \mathrm{~W}^{2}+0.135 \mathrm{~W}-0.7513 \\
\frac{\partial\left(\gamma_{\mathrm{d}}\right)}{\partial \mathrm{W}}=0 \text { say }-0.0045 \mathrm{~W}_{\mathrm{OP}}^{2}+ \\
+0.135 \mathrm{~W}_{\mathrm{OP}}-0.7513=0 \\
\mathbf{W}_{\mathrm{OP}}=\mathbf{2 2 . 6 1} \%
\end{gathered}
$$




$$
\begin{gathered}
\gamma_{\mathrm{d} \max }=-0.0015 \mathrm{~W}_{\mathrm{OP}}^{3}+0.0675 \mathrm{~W}_{\mathrm{OP}}^{2}- \\
-0.7513 \mathrm{~W}_{\mathrm{OP}}+16.975 \\
\gamma_{\mathrm{dmax}}=-0.0015\left(22.61^{3}\right)+0.0675\left(22.61^{2}\right)- \\
-0.7513(22.61)+16.975 \\
\gamma_{\mathrm{d} \max }=\mathbf{1 7 . 1 6} \mathbf{k N} . \mathbf{m}^{-3}
\end{gathered}
$$

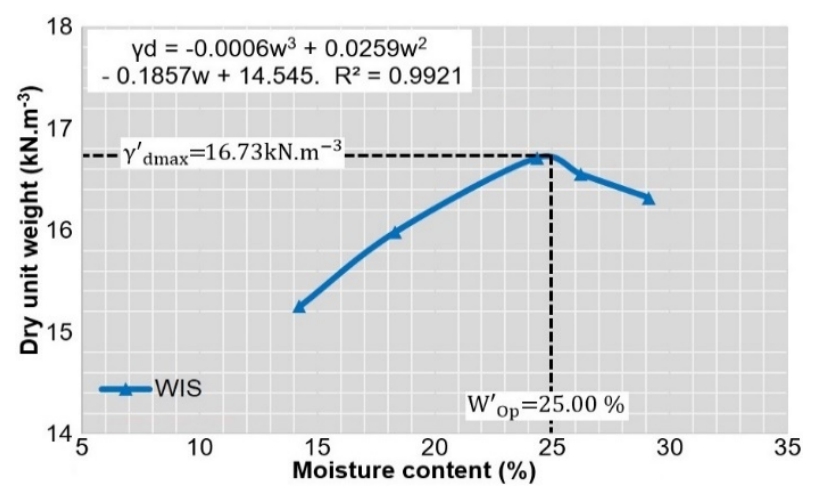

Figure 5. Compaction curve graph, $\gamma_{\mathrm{d}}=f(\mathrm{~W})$, (WIS)

Compaction characteristic values $\left(\gamma_{\mathrm{dmax}}, \mathrm{W}_{\mathrm{OP}}\right)$ of WIS fine-grained soils are obtained using the graphical method.

$$
\begin{gathered}
\mathbf{W}_{\mathrm{OP}}^{\prime}=25.00 \% \\
\gamma_{\mathrm{dmax}}^{\prime}=16.73 \mathrm{kN} . \mathrm{m}^{-3}
\end{gathered}
$$

Compaction characteristic values $\left(\gamma_{\mathrm{dmax}}, \mathrm{W}_{\mathrm{OP}}\right)$ of WIS fine-grained soils are obtained using the mathematical approach.

$$
\begin{aligned}
& \gamma_{d}=-0.0006 W^{3}+0.0259 W^{2}- \\
& -0.1857 \mathrm{~W}+14.545 \\
& \frac{\partial\left(\gamma_{\mathrm{d}}\right)}{\partial \mathrm{w}}=-0.0018 \mathrm{~W}^{2}+0.0518 \mathrm{~W}-0.1857 \\
& \frac{\partial\left(\gamma_{\mathrm{d}}\right)}{\partial \mathrm{w}}=0 \text { say }-0.0018 \mathrm{~W}_{\mathrm{OP}}^{2}+ \\
& +0.0518 \mathrm{~W}_{\mathrm{OP}}-0.1857=0 \\
& \mathbf{W}_{\mathrm{OP}}=\mathbf{2 4 . 5 8 \%} \\
& \gamma_{\mathrm{dmax}}=-0.0006 \mathrm{~W}_{\mathrm{OP}}{ }^{3}+0.0259 \mathrm{~W}_{\mathrm{OP}}{ }^{2}- \\
& -0.1857 \mathrm{~W}_{\mathrm{OP}}+14.545 \\
& \gamma_{\mathrm{dmax}}=-0.0006\left(24.58^{3}\right)+0.0259\left(24.58^{2}\right)- \\
& -0.1857(24.58)+14.545 \\
& \gamma_{\mathrm{dmax}}=16.71 \mathrm{kN} \cdot \mathrm{m}^{-3}
\end{aligned}
$$

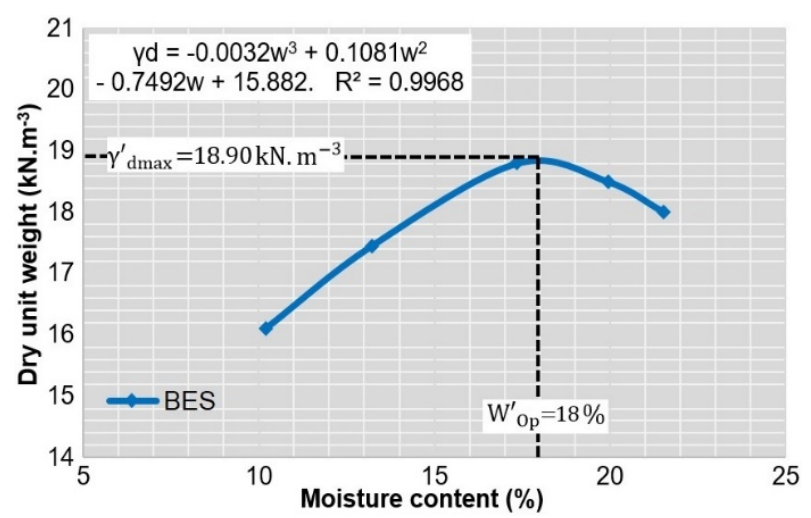

Figure 6. Compaction curve graph, $\gamma_{\mathrm{d}}=f(\mathrm{~W}),(\mathrm{BES})$

Compaction characteristic values $\left(\gamma_{\mathrm{dmax}}, \mathrm{W}_{\mathrm{OP}}\right)$ of BES fine-grained soils are obtained using the graphical method.

$$
\begin{gathered}
\mathbf{W}^{\prime}{ }_{\text {OP }}=18 \% \\
\gamma_{\text {dmax }}^{\prime}=18.90 \mathrm{kN} \cdot \mathrm{m}^{-3}
\end{gathered}
$$

Compaction characteristic values $\left(\gamma_{\mathrm{dmax}}, \mathrm{W}_{\mathrm{OP}}\right)$ of BES fine-grained soils are obtained using the mathematical approach.

$$
\begin{aligned}
& \gamma_{\mathrm{d}}=-0.0032 \mathrm{~W}^{3}+0.1081 \mathrm{~W}^{2}- \\
& -0.7492 W+15.882 \\
& \frac{\partial\left(\gamma_{\mathrm{d}}\right)}{\partial \mathrm{w}}=-0.0096 \mathrm{~W}^{2}+0.2162 \mathrm{~W}-0.7492 \\
& \frac{\partial\left(\gamma_{\mathrm{d}}\right)}{\partial \mathrm{w}}=0 \text { say }-0.0096 \mathrm{~W}_{\mathrm{OP}}^{2}+ \\
& +0.2162 \mathrm{~W}_{\mathrm{OP}}-0.7492=0 \\
& \mathbf{W}_{\mathrm{OP}}=18.24 \% \\
& \gamma_{\mathrm{dmax}}=-0.0032\left(\mathrm{~W}_{\mathrm{OP}}{ }^{3}\right)+0.1081\left(\mathrm{~W}_{\mathrm{OP}}{ }^{2}\right)- \\
& -0.7492\left(\mathrm{~W}_{\mathrm{OP}}\right)+15.882 \\
& \gamma_{\mathrm{dmax}}=-0.0032\left(18.24^{3}\right)+0.1081\left(18.24^{2}\right)- \\
& -0.7492(18.24)+15.882 \\
& \gamma_{\mathrm{dmax}}=18.76 \mathrm{kN} \cdot \mathrm{m}^{-3}
\end{aligned}
$$

\subsubsection{Soil suction and water content relationship}

The relationship between soil suction and water content for each soil specimen is studied. Figures 7, 8, $9 \& 10$ show a variation in total suction, matric suction, and osmotic suction related to water content respectively for soils PES, BFS, WIS, BES. The change in total suction is fundamentally equivalent to a variation in matric suction and vice versa. The curve of total suction is located above the matric suction curve and is very similar in shape. Besides, the shape of the osmotic suction curve is different from the one of matric and total suctions. The matric suction contribution to the total suction is higher than the osmotic suction contribution. Further, WIS exhibits higher suction values, BES displays smaller suction values, and BFS, PES exhibit mean suction values. That is justified by the fact that WIS contained a higher clay fraction of $36.50 \%$, BES contained a smaller clay fraction of $20.00 \%$. BFS and PES contained respective $32.20 \%, 29.85 \%$ clay fraction. Moreover, the results are in line with the research work performed by Fredlund and Xing (1994) on the SWCC of various types of soils. They reported that soil specimen with a higher clay fraction displays a higher soil suction at the same water content than soil specimen with a smaller clay fraction. On the other hand, the soil suction equation of the soil samples is as follows: PES suction trend line equations are $\Psi_{\mathrm{t}}=(23.147-\mathrm{W}) / 0.0024, \Psi_{\mathrm{m}}=$ $(23.05-\mathrm{W}) / 0.0029$ with respective determination coefficients of $89.01 \%$ and $90.00 \%$. BFS trend line equations are $\Psi_{\mathrm{t}}=(26.69-\mathrm{W}) / 0.0025, \quad \Psi_{\mathrm{m}}=$ $(26.31-\mathrm{W}) / 0.0031$ with respective determination 
coefficients of $93.55 \%$ and $92.03 \%$. WIS suction trend line equations are $\Psi_{\mathrm{t}}=(28.512-\mathrm{W}) / 0.0024, \quad \Psi_{\mathrm{m}}=$ $(26.008-\mathrm{W}) / 0.0029$ with respective determination coefficients of $97.75 \%$ and $97.24 \%$. BES suction trend line equations are $\Psi_{\mathrm{t}}=(19.193-\mathrm{W}) / 0.0025, \quad \Psi_{\mathrm{m}}=$ $(18.953-\mathrm{W}) / 0.0030$ with respective determination coefficients of $93.05 \%$ and $90.74 \%$. In general, there is a strong correlation between the soil suctions (total suction, matric suction) and the water content. Therefore, these equations can describe precisely the total and matric suction at the $\mathrm{W}_{\mathrm{OP}}$ using the mathematical approach and graphical method.

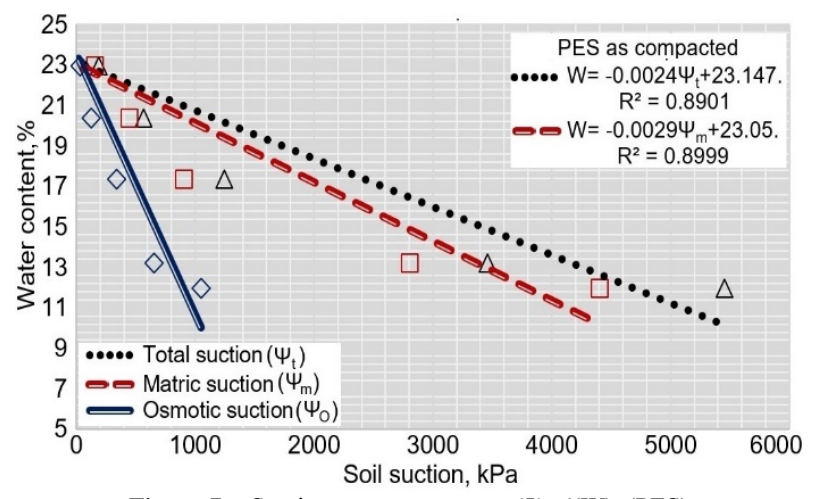

Figure 7. Suction vs water content, $\Psi=f(\mathrm{~W})$, (PES)

$$
\begin{aligned}
& \psi_{\mathrm{t}}=\frac{23.147-\mathrm{W}}{0.0024} \\
& \psi_{\mathrm{m}}=\frac{23.050-\mathrm{W}}{0.0029}
\end{aligned}
$$

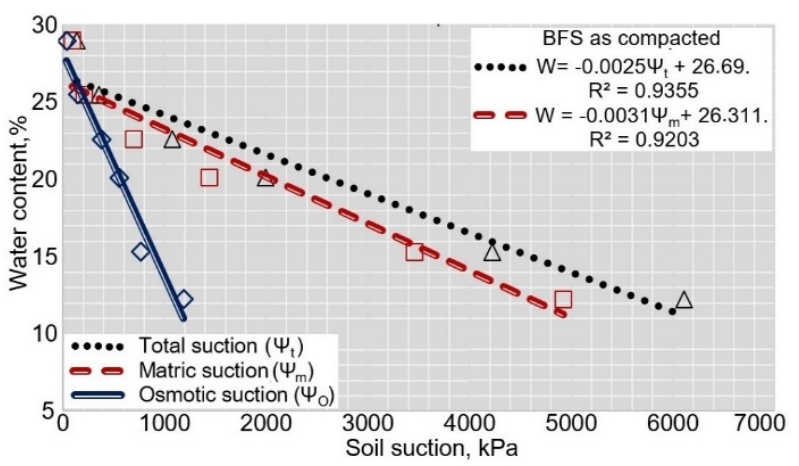

Figure 8. Suction vs water content, $\Psi=f(\mathrm{~W}),(\mathrm{BFS})$

$$
\begin{aligned}
& \psi_{\mathrm{t}}=\frac{26.69-\mathrm{W}}{0.0025} \\
& \psi_{\mathrm{m}}=\frac{26.311-\mathrm{W}}{0.0031}
\end{aligned}
$$

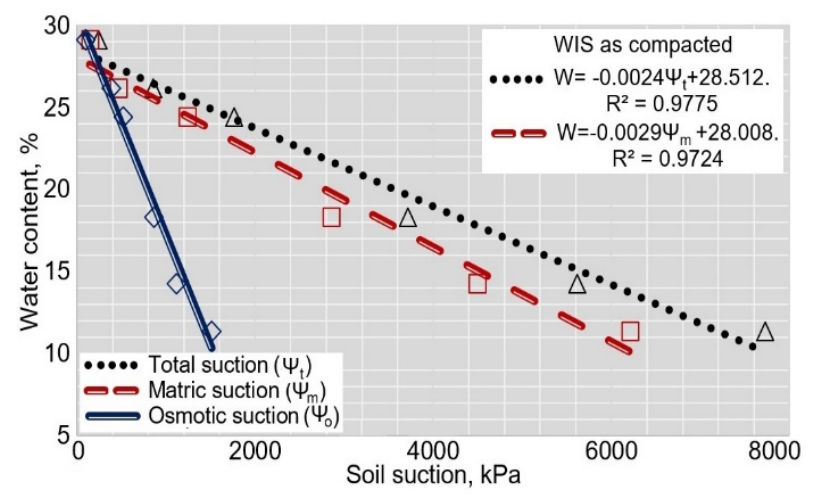

Figure 9. Suction vs water content, $\Psi=f(\mathrm{~W})$, (WIS)

$$
\begin{aligned}
\psi_{\mathrm{t}} & =\frac{28.512-\mathrm{W}}{0.0024} \\
\psi_{\mathrm{m}} & =\frac{23.008-\mathrm{W}}{0.0029}
\end{aligned}
$$

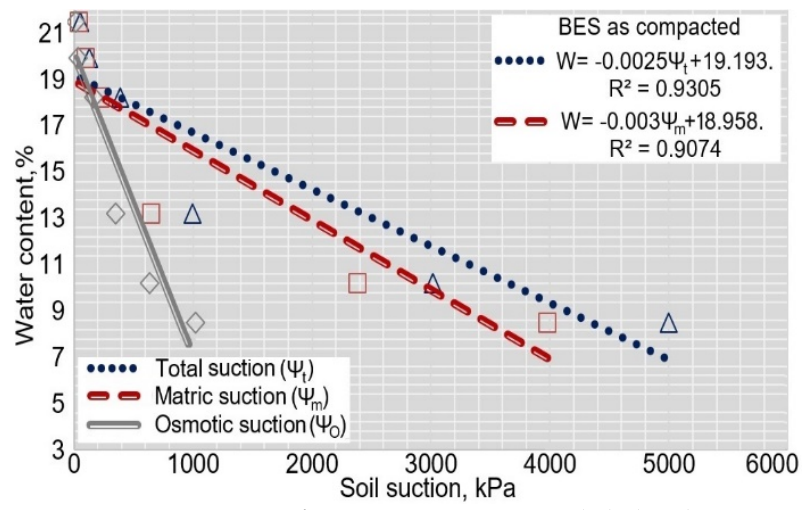

Figure 10. Suction vs water content, $\Psi=f(\mathrm{~W}),(\mathrm{BES})$

$$
\begin{aligned}
& \psi_{\mathrm{t}}=\frac{19.193-\mathrm{W}}{0.0025} \\
& \psi_{\mathrm{m}}=\frac{18.953-\mathrm{W}}{0.0030}
\end{aligned}
$$




\subsection{Assessment of the Impact of the Difference between the Mathematical Approach and Graphical Method on Soil Suction at $\mathbf{W}_{\mathrm{OP}}$}

The assessment of the impact of the difference at WOP between the mathematical approach and the graphical method on the total suction and matric suction is summarized respectively in Tables $3 \& 4$. The differences in $\mathrm{W}_{\mathrm{OP}}$ value between graphical method and mathematical approach $\left(\Delta \mathrm{W}_{\mathrm{OP}}\right)$ are $0.43 \%, 0.36 \%, 0.42 \%, 0.24 \%$, respective for soils PES, BFS, WIS, BES. In Table 3, Equations 48, 50, 52, 54 are utilized to calculate the total suction values at $\mathrm{W}_{\mathrm{OP}}$ denoted by $\Psi_{\mathrm{t}}\left(\mathrm{W}_{\mathrm{OP}}\right)$ and $\Psi_{\mathrm{t}}\left(\mathrm{W}_{\mathrm{OP}}^{\prime}\right)$. $\mathrm{W}_{\mathrm{OP}}$ and $\mathrm{W}_{\mathrm{OP}}^{\prime}$ are the optimum moisture content given respectively for the mathematical approach and graphical method. $\Psi_{\mathrm{t}}\left(\mathrm{W}_{\mathrm{OP}}\right)$ values are $1152.92 \mathrm{kPa}, 1632.00 \mathrm{kPa}$, $1638.33 \mathrm{kPa}, 381.20 \mathrm{kPa}$, respectively for PES, BFS, WIS, BES. Also, $\Psi_{\mathrm{t}}\left(\mathrm{W}_{\mathrm{OP}}^{\prime}\right)$ values are $1332.08 \mathrm{kPa}, 1776.00 \mathrm{kPa}$, $1463.33 \mathrm{kPa}, 477.20 \mathrm{kPa}$ respectively for PES, BFS, WIS, BES. The difference in total suction at the $\mathrm{W}_{\mathrm{OP}}$ between mathematical approach value $\Psi_{\mathrm{t}}\left(\mathrm{W}_{\mathrm{OP}}\right)$ and graphical method value $\Psi_{\mathrm{t}}\left(\mathrm{W}_{\mathrm{OP}}^{\prime}\right)$ is denoted by $\Delta \Psi_{\mathrm{t}}\left(\mathrm{W}_{\mathrm{OP}}\right)$ and calculated using Equation 56.

$$
\Delta \psi_{\mathrm{t}}\left(\mathrm{W}_{\mathrm{OP}}\right)=\left|\psi_{\mathrm{t}}\left(\mathrm{W}_{\mathrm{OP}}\right)-\psi_{\mathrm{t}}\left(\mathrm{W}_{\mathrm{OP}}^{\prime}\right)\right|
$$

In Table 4, Equations 49, 51, 53, 55 are used to calculate the matric suction at $\mathrm{W}_{\mathrm{OP}}$ denoted by $\Psi_{\mathrm{m}}\left(\mathrm{W}_{\mathrm{OP}}\right)$ and $\Psi_{\mathrm{m}}$
$\left(\mathrm{W}_{\mathrm{OP}}^{\prime}\right) . \mathrm{W}_{\mathrm{OP}}$ and $\mathrm{W}_{\mathrm{OP}}^{\prime}$ are the are the optimum moisture content given respectively for the mathematical approach and graphical method. $\Psi_{\mathrm{m}}\left(\mathrm{W}_{\mathrm{OP}}\right)$ values are $920.69 \mathrm{kPa}$, $1193.87 \mathrm{kPa}, 1182.07 \mathrm{kPa}, 237.67 \mathrm{kPa}$ respectively for PES, BFS, WIS, BES. Moreover, $\Psi_{\mathrm{m}}\left(\mathrm{W}_{\mathrm{OP}}^{\prime}\right)$ values are $1068.97 \mathrm{kPa}, 1310.00 \mathrm{kPa}, 1037.24 \mathrm{kPa}, 317.67 \mathrm{kPa}$, respectively for PES, BFS, WIS, BES. The difference in matric suction at the $\mathrm{W}_{\mathrm{OP}}$ between mathematical approach value $\Psi_{\mathrm{m}}\left(\mathrm{W}_{\mathrm{OP}}\right)$ and graphical method value $\Psi_{\mathrm{m}}\left(\mathrm{W}_{\mathrm{OP}}^{\prime}\right)$ is denoted by $\Delta \Psi_{\mathrm{m}}\left(\mathrm{W}_{\mathrm{OP}}\right)$ and determine from Equation 57.

$$
\Delta \psi_{\mathrm{m}}\left(\mathrm{W}_{\mathrm{OP}}\right)=\left|\psi_{\mathrm{m}}\left(\mathrm{W}_{\mathrm{OP}}\right)-\psi_{\mathrm{m}}\left(\mathrm{W}_{\mathrm{OP}}^{\prime}\right)\right|
$$

The differences in optimum moisture content between the mathematical approach values and graphical method values $\left(\Delta \mathrm{W}_{\mathrm{OP}}\right)$ are $0.43 \%, 0.36 \%, 0.42 \%, 0.24 \%$ respectively for soils PES, BFS, WIS, BES and induce a difference in total suction of $179.17 \mathrm{kPa}, 144.00 \mathrm{kPa}$, $175.00 \mathrm{kPa}, 96.00 \mathrm{kPa}$, and a difference in matric suction of $148.27 \mathrm{kPa}, 116.13 \mathrm{kPa}, 144.83 \mathrm{kPa}, 80.00 \mathrm{kPa}$, respectively for soils PES, BFS, WIS, BES. Although $\Delta \mathrm{W}_{\mathrm{OP}}$ values are marginal, the total suction and matric suction values induced by $\Delta \mathrm{W}_{\mathrm{OP}}$ are significant in the context of unsaturated soil mechanics. Therefore, the mathematical approach is more accurate and efficient than the graphical method in assessing the compaction characteristics in unsaturated soils.

\begin{tabular}{|c|c|c|c|c|c|c|}
\hline \multirow[t]{2}{*}{$\begin{array}{c}\text { Soil } \\
\text { designation }\end{array}$} & $\begin{array}{l}\text { OMC using } \\
\text { mathematical } \\
\text { approach } \\
\%\end{array}$ & $\begin{array}{l}\text { OMC using } \\
\text { graphical } \\
\text { Method, } \\
\%\end{array}$ & $\begin{array}{c}\text { Difference in } \\
\text { OMC } \\
\%\end{array}$ & $\begin{array}{c}\text { Total } \\
\text { suction } \\
\psi_{\mathrm{t}} \text { in } \mathrm{kPa} @ \\
\text { OMC using } \\
\mathrm{W}_{\mathrm{OP}} \\
\end{array}$ & $\begin{array}{c}\text { Total } \\
\text { suction in } \mathrm{kPa} \\
@ \\
\text { OMC using } \\
\mathrm{W}_{\text {OP }}^{\prime}\end{array}$ & $\begin{array}{c}\text { Difference total } \\
\text { suction in } \mathrm{kPa} @ \\
\text { OMC }\end{array}$ \\
\hline & $\mathrm{W}_{\mathrm{OP}}$ & $\mathrm{W}_{\mathrm{OP}}^{\prime}$ & $\begin{array}{c}\Delta \mathrm{W}_{\mathrm{Op}}= \\
\left|\mathrm{W}_{\mathrm{OP}}-\mathrm{W}^{\prime}{ }_{\mathrm{OP}}\right|\end{array}$ & $\psi_{\mathrm{t}}\left(\mathrm{W}_{\mathrm{OP}}\right)$ & $\psi_{\mathrm{t}}\left(\mathrm{W}_{\mathrm{OP}}^{\prime}\right)$ & $\begin{array}{c}\Delta \psi_{\mathrm{t}}\left(\mathrm{W}_{\mathrm{OP}}\right)= \\
\mid \psi_{\mathrm{t}}\left(\mathrm{W}_{\mathrm{OP}}\right) \\
-\psi_{\mathrm{t}}\left(\mathrm{W}^{\prime}{ }_{\mathrm{OP}}\right) \mid\end{array}$ \\
\hline PES & 20.38 & 19.95 & 0.43 & 1152.92 & 1332.08 & 179.17 \\
\hline BFS & 22.61 & 22.25 & 0.36 & 1632.00 & 1776.00 & 144.00 \\
\hline WIS & 24.58 & 25.00 & 0.42 & 1638.33 & 1463.33 & 175.00 \\
\hline BES & 18.24 & 18.00 & 0.24 & 381.20 & 477.20 & 96.00 \\
\hline
\end{tabular}

Table 3. Differences in OMC and Total suction

\begin{tabular}{|c|c|c|c|c|c|c|}
\hline \multirow[t]{2}{*}{$\begin{array}{c}\text { Soil } \\
\text { designation }\end{array}$} & $\begin{array}{c}\text { OMC using } \\
\text { mathematical } \\
\text { approach } \\
\%\end{array}$ & $\begin{array}{c}\text { OMC using } \\
\text { graphical } \\
\text { Method, } \\
\%\end{array}$ & $\begin{array}{c}\text { Difference } \\
\text { in OMC, } \\
\%\end{array}$ & $\begin{array}{c}\text { Matric } \\
\text { suction in } \\
\mathrm{kPa} @ \text { OMC } \\
\text { using } \\
\mathrm{W}_{\mathrm{OP}} \\
\end{array}$ & $\begin{array}{c}\text { Matric } \\
\text { suction in } \mathrm{kPa} \\
@ \\
\text { OMC using } \\
\mathrm{W}_{\mathrm{OP}}^{\prime} \\
\end{array}$ & $\begin{array}{c}\text { Difference } \\
\text { matric suction in } \\
\text { kPa@ } \\
\text { OMC }\end{array}$ \\
\hline & $\mathrm{W}_{\mathrm{OP}}$ & $\mathrm{W}_{\mathrm{OP}}^{\prime}$ & $\begin{array}{c}\Delta \mathrm{W}_{\mathrm{Op}}= \\
\left|\mathrm{W}_{\mathrm{OP}}-\mathrm{W}^{\prime}{ }_{\mathrm{OP}}\right|\end{array}$ & $\psi_{\mathrm{m}}\left(\mathrm{W}_{\mathrm{OP}}\right)$ & $\Psi_{\mathrm{m}}\left(\mathrm{W}_{\mathrm{OP}}^{\prime}\right)$ & $\begin{array}{c}\Delta \psi_{\mathrm{m}}\left(\mathrm{W}_{\mathrm{OP}}\right)= \\
\mid \psi_{\mathrm{m}}\left(\mathrm{W}_{\mathrm{OP}}\right) \\
-\psi_{\mathrm{m}}\left(\mathrm{W}^{\prime}{ }_{\mathrm{OP}}\right) \mid\end{array}$ \\
\hline PES & 20.38 & 19.95 & 0.43 & 920.69 & 1068.97 & 148.27 \\
\hline BFS & 22.61 & 22.25 & 0.36 & 1193.87 & 1310 & 116.13 \\
\hline WIS & 24.58 & 25.00 & 0.42 & 1182.07 & 1037.24 & 144.83 \\
\hline BES & 18.24 & 18.00 & 0.24 & 237.67 & 317.67 & 80.00 \\
\hline
\end{tabular}

Table 4. Differences in OMC and Matric suction 


\section{Concluding Remarks}

The objective of the research work is to propose a mathematical approach to assess the compaction characteristics of unsaturated fine-grained clay soils. Soil properties are determined using lab tests such as grain size distribution, Atterberg limits, specific gravity, Proctor compaction test, and soil suction measurement. A mathematical approach and graphical method are utilized to determine the compaction characteristics. The $\Delta \mathrm{W}_{\mathrm{OP}}$ values are $0.43 \%, 0.36 \%, 0.42 \%, 0.24 \%$ respectively for soils PES, BFS, WIS, BES, and induce differences in total suction of $179.17 \mathrm{kPa}, 144.00 \mathrm{kPa}, 175.00 \mathrm{kPa}$, $96.00 \mathrm{kPa}$ for respective soils PES, BFS, WIS, BES. Moreover, the differences in matric suction are 148.27 $\mathrm{kPa}, 116.13 \mathrm{kPa}, 144.83 \mathrm{kPa}, 80.00 \mathrm{kPa}$ respectively for soil PES, BFS, WIS, BES. The $\Delta$ WOP and $\Delta \gamma_{\text {dmax }}$ values are smaller than $0.5 \%$ and marginal in saturated soil mechanics. However, the total suction and the matric suction values induced by $\Delta \mathrm{W}_{\mathrm{OP}}$ are significant for unsaturated soils. Finally, the mathematical approach leads to an accurate estimation of the compaction characteristics of unsaturated fine-grained clay soils.

\section{REFERENCES}

[1] Olufemi Ogunsanwo, "Geotechnical Properties of Undisturbed and Compacted Amphibolite Derived Laterite Soil," Bulletin of the International Association of Engineering Geology, vol. 42, no. 1, pp. 67-73, 1990. DOI: 10.1007/BF02592621.

[2] Jack W. Hilf, "A Rapid Method of Construction Control for Embankments of Cohesive Soil," Engineering Monograph, no 26, pp. 1-29, 1956.

[3] Georges W. Ring, John R. Sallberg, Webster H. Collins, "Correlation of Compaction and Classification Test Data," Highway. Research Bulletin, No. 325, pp. 55-75, 1962.

[4] BK. Ramaiah, V. Viswanath, HV. Krishnamurthy, "Interrelationship of Compaction and Index Properties," The Second South East Asian Conference on Soil Engineering, Singapore, 1970, pp. 577-587.

[5] Mian C. Wang, Chin-Chuan Huang, "Soil Compaction and Permeability Prediction Models," Journal of Environmental Engineering, vol. 110, no. 6, pp. 1063-1083, 1984. DOI: 10.1061/(ASCE)0733-9372(1984)110:6(1063).

[6] SABS, "Civil Engineering Test Methods, Determination of the Maximum Dry Density and Optimum Moisture Content," SANS 3001, Part GR30, South Africa Bureau of Standards. Pretoria, 2016.

[7] Ksenija Đoković, Dragoslav Rakić, Milenko Ljubojev,
"Estimation of Soil Compaction Parameters Based on the Atterberg Limits," Mining and Metallurgy Engineering Bor, no. 4, pp. 1-16, 2013. DOI: 10.5937/mmeb1304001D.

[8] Kok Shien Ng, Yee Ming Chew, Mohammad Hafeez Osman, SK. Mohamad Ghazali, "Estimating Maximum Dry Density and Optimum Moisture Content of Compacted Soils," The International Conference on Advances in Civil and Environmental Engineering, Pulau Pinang, Malaysia, 2015. https://www.researchgate.net/publication/280734291 (accessed Sept. 05, 2020).

[9] K. Hannah Jyothirmayi, Taminneni. Gnanananda, Kommo Suresh, "Prediction of Compaction Characteristics of Soil Using Plastic Limit," International Journal of Research in Engineering and Technology, vol. 4, no. 1, pp. 253-256, 2015.

https:/ijret.org/volumes/2015v04/i06/IJRET20150406042. pdf (accessed Sept. 06, 2020).

[10] Binu Sharma, Asuri Sridharan, Pran Hari Talukdar, "Static Method to Determine Compaction Characteristics of Fine-Grained Soils, "Geotechnical Testing Journal, vol. 39, no. 6, pp.1048-1055, 2016. DOI: 10.1520/GTJ20150221.

[11] Worku Firomsa Kabeta, Emer Tucay Quezon, "Parametric Modelling on the Relationships Between Atterberg Limits and Compaction Characteristics of Fine-grained Soils," International Journal of Advanced Research in Engineering and Applied Sciences, vol. 8, no. 7, pp. 1-20, 2019. https://www.researchgate.net/publication/334737749 (accessed Sept. 05, 2020).

[12] Jun Chen, Hao Wang, Yangping Yao, "Determination of Optimum Moisture Content of a Clay Using Nonlinear Ultrasonic Technique," Japanese Geotechnical Society Special Publication, vol. 1, no. 2, pp. 1-5, 2015. DOI: 10.3208/jgssp.CPN-02.

[13] Azhar Sadiq Yasun, Jamal N. Al Abbasi, "A Proposed Approach for Evaluating Soils Optimum Moisture Content Arithmetically and Use Statistical Functions for Checking Method," International Journal of Engineering \& Technology, vol. 7, no 4, pp. 287-292, 2018. DOI: 10.14419/ijet.v7i4.20.25941.

[14] ASTM, "Standard Test Method for Particle-Size Distribution (Gradation) of Soils Using Sieve Analysis," D 6913; 04. 09, American Society for Testing and Materials, PA, USA, 2009. DOI: 10.1520/d6913-04r09.

[15] ASTM, "Standard Test Method for Particle-size Distribution (Gradation) of Fine-Grained Soils Using the Sedimentation (Hydrometer) Analysis," D7928; 04. 09, American Society for Testing and Materials, PA, USA, 2016. DOI: 10.1520/d7928-16e01.

[16] ASTM, "Standard Test Method for Liquid Limit, Plastic Limit, and Plasticity Index of Soils," D 4318; 04. 08, American Society for Testing and Materials, PA, USA, 2005. DOI: $10.1520 / \mathrm{d} 4318-17 \mathrm{e} 01$.

[17] ASTM, "Standard Test Method for Measurement of Soil potential (Suction) using filter paper," D 5298; 04. 08, American Society for Testing and Materials, PA, USA, 2016. DOI: $10.1520 / \mathrm{d} 5298-16$. 